\title{
The Influence of International Case Law on Aspects of International Law Relating to the Conservation of Living Marine Resources beyond National Jurisdiction
}

\author{
Simone Borg
}

\section{INTRODUCTION}

Under international law, there is no single legal body with the power to generate norms that are binding on all subjects without their consent. ${ }^{1}$ There is no centralized executive authority entrusted with implementation, while international adjudicating bodies have no compulsory or comprehensive jurisdiction. Apart from the absence of a centralized law-making and law-enforcement authority, most publicists insist that with the exception of jus cogens, ${ }^{2}$ there is no a priori hierarchy of sources under international law. ${ }^{3}$ This state of play is of particular relevance when one assesses the role of international adjudicating bodies as they settle disputes between states. ${ }^{4}$ International case law, like the writings of publicists, is not a formal source of international law but, rather, provides 'evidence' of the applicable norms in the circumstances. ${ }^{5}$ Decisions of the International Court of Justice (ICJ) and other international adjudicating bodies are binding only upon the parties to the dispute. ${ }^{6}$ Nevertheless, by taking as an example the conservation of living marine resources beyond national jurisdiction, this article attempts to demonstrate that the contribution made by the ICJ and other international tribunals to the development of international law may be more significant, especially when one considers the scenario referred to earlier.

This article will examine various judgments of the ICJ and other international tribunals and assess their role and relevance in the development of the international regulation of living marine resources occurring beyond national jurisdiction. The way states interpret the freedom of access over living resources on the

1 I Brownlie, Principles of Public International Law, at 1 (7th edition, 2008).

2 Vienna Convention on the Law of Treaties, 8 ILM 679 (1969), Articles 53 and 64 [VCLT]. See also MN Shaw, International Law, at 123-24 (6th edition, 2008).

3 See Brownlie, supra note 1 at 5; see also J Pauwelyn, Conflict of Norms in Public International: How WTO Relates to Other Rules of International Law, Cambridge Studies in International and Comparative Law, at 94 et seq (2003).

4 The International Court of Justice (ICJ) may also be requested by the organs and duly authorized bodies or agencies of the United Nations to give an advisory opinion on the position of international law relating to a matter of international concern.

5 Statute of the ICJ, Article 38(d) and Article 59.

6 Ibid, Article 59.

(C) The Author 2013. Published by Oxford University Press. All rights reserved. For permissions, please e-mail: journals.permissions@oup.com 
high seas determines the manner in which they exercise regulatory and enforcement jurisdiction over them as well as the kind of conservation measures states obligate their nationals to take when fishing in marine areas beyond national jurisdiction. ${ }^{7}$ Bodies adjudicating international disputes over the exploitation of living marine resources have considered various legal issues in this field of international law, the following being among the most common. First, states tend to disagree on how they interpret the legal implications of freedom of fishing and the obligation to take conservation measures as a qualification to it. The article will examine those fisheries cases that have discussed to what extent the flag state's freedom of access over living marine resources on the high seas is subject to the rights, duties, and interests of coastal states and of other flag state participants in the same fishery.

Second, another contentious legal issue relates to the interpretation of the exclusive enforcement jurisdiction of the flag state and to whether international law allows other states any right to act against states that either fail to adopt conservation measures on the high seas or that choose less stringent ones than those agreed upon via international co-operation agreements. This legal question revolves around the abuse of the flag state's exclusive enforcement jurisdiction on the high seas. It affects both coastal states that have painstakingly developed a conservation plan for their exclusive economic zone (EEZ) or their exclusive fishing zone (EFZ) as well as states that are participants in the same high seas fishery and that have negotiated conservation measures via a co-operation agreement. In the first case, the coastal state expects flag states to exercise compatible conservation measures when their nationals fish on the high seas, and, in the second case, flag states, whose nationals are participating in a fishery, find it particularly frustrating and counter productive when another flag state who is not a party to the conservation agreement reached via co-operation takes no action against its fishing vessels that violate the conservation measures established in the agreement or else adopt inferior ones.

Third, another question that often arises in international fisheries disputes relates to the legal status of living marine resources occurring beyond national jurisdiction and whether international law obligates all states to ensure the conservation of living marine resources on the high seas whether they are harvestable or not. The debate surrounding the legal status of these resources also questions whether the obligation to take conservation measures on the high seas is vested in the international community at large as an erga omnes obligation. The cohort of rules regulating the conservation of marine living resources on the high seas has developed on an ad hoc basis, as a reaction to the historical and political developments that have occurred throughout the centuries. ${ }^{8}$ As it has become more and more specialized, this branch of international law has

${ }^{7}$ Brownlie, supra note 1 at 252-53.

${ }^{8}$ For a brief historical account on the development of the law of the sea, see ibid at 224-25. 
suffered from fragmentation, ${ }^{9}$ which has led to ambiguity and uncertainty when states have sought to interpret and apply applicable norms. The decisions of international adjudicating bodies provide the judges with an opportunity to identify what is the position of international law from the myriad of norms that have accumulated over time. This article will attempt to examine various international cases that have discussed the position of international law in fisheries disputes. Occasionally, it will also refer to some other landmark cases that have treated an entirely different subject matter whenever the legal arguments made by the judges therein may elucidate the interpretation of applicable international norms relating to the legal questions listed earlier.

II. INTERNATIONAL CASE LAW ON RIGHT OF ACCESS OVER LIVING MARINE RESOURCES ON THE HIGH SEAS AND THE QUALIFICATIONS TO THE FREEDOM OF FISHING

1. The Freedom of Fishing and Reasonable Use to Ensure Access to the Same Resources by Other States

In 1893, an international dispute arose between the United States and the United Kingdom over the rights of jurisdiction of the United States in the Behring's Sea and the preservation of fur seals. The United States wanted to prohibit sealing beyond its territorial waters by British flagged vessels because the seal colony was based in its own territory. In the Behring Sea (Fur Seals) Arbitration Award, the arbitrators not only reaffirmed the principle of freedom of fishing beyond national jurisdiction but also recognized the need for restraint and called upon both states to co-operate in regulating the seals' over-exploitation on the high seas. ${ }^{10}$ The Behring Sea case supported the interpretation that the freedom to fish was not absolute but had to take 'reasonable account of the interests of other States. ${ }^{11}$ The arbitrators considered that conservation measures were necessary to ensure that the other participants' rights of access to the same resources on the high seas were not prejudiced. So by the end of the nineteenth century, the Behring Sea case had already chastised abuse of the right of freedom of fishing and referred to the interest that other stakeholders have over such resources. The award ruled against the legality of any unilateral measures that hinder the freedom of access by other states to living resources on the high seas. The Behring Sea case identified co-operation as the means permitted by international law to ensure the conservation of the species so as to prevent over-exploitation that

9 Diversification and Expansion of International Law: Fragmentation of International Law: Difficulties Arising from Diversification and Expansion of International Law, Report of the Study Group of the International Law Commission (2006) [Diversification and Expansion].

10 Behring Sea (Fur Seals) Arbitration Award (1898), 1 Moore's International Arbitration Awards 755, [1974] ICJ Rep 3, reprinted in (1999) 1 International Environmental Law Reports 43.

11 Ibid at para 43 . 
may lead to their extinction. It proposed a conservation plan for the parties and even for other states involved in the exploitation of the fur seals.

The decision reached by the arbitrators in the Behring Sea case not only provided evidence as to what were (and to some extent still are) the applicable international norms but also served to influence the trend in international fisheries law for many years to the extent that its line of reasoning was included in the 1958 Convention on the High Seas. ${ }^{12}$ This convention established that states shall exercise the freedoms ${ }^{13}$ with 'reasonable regard to the interests of States in their exercise of the freedoms of the high seas.' The 1958 Convention on Fishing and Conservation of the Living Resources of the High Seas (High Seas Fishing Convention) did not only refer to the interests of states whose nationals fish on the high seas but also reiterated the right of freedom of fishing subject to coastal states' rights. ${ }^{14}$ In the 1974 Fisheries Jurisdiction Cases (United Kingdom v Iceland and Germany v Iceland), the ICJ was asked to decide upon the legality of Iceland's extension of its fisheries jurisdiction and the rights of the United Kingdom and Germany as flag states whose nationals fish in the area. ${ }^{15}$ The relevance of the Fisheries Jurisdiction cases in this discussion revolves around the qualifications to the freedom of fishing due to the relative nature of the rights of other states involved in a fishery on the high seas. The ICJ upheld as customary international law Germany's and the United Kingdom's right to exercise freedom of fishing. It declared that the parties' respective rights, both as high seas fishing states and as coastal states, were not absolute but 'had to take full account of each other's rights and of any fishery conservation measures.' 16

The decision of the ICJ in the 1974 Fisheries Jurisdiction cases also referred to the rights of access to living resources on the high seas but emphasized the obligation of reasonable use, the need of conservation, equitable allocation, and good faith between the parties when entering into negotiations. This approach reflects the views of the ICJ in another case, namely the North Sea Continental Shelf Cases (Germany v Netherlands and Germany v Denmark), where it had stated that negotiations must be meaningful and each side must listen to and take into account each others' interests. ${ }^{17}$ In the Fisheries Jurisdiction cases, the ICJ

12 Convention on the High Seas, 450 UNTS 11.

13 Ibid, Article 2, which establishes that '[f]reedom of the high seas is exercised under the conditions laid down by these articles and by other rules of International law and comprises inter alia both for coastal and non coastal States ... the freedom of fishing.'

14 Article 1 of the 1958 Convention on Fishing and Conservation of the Living Resources of the High Seas, 559 UNTS 285 [High Seas Fishing Convention], establishes that '[a]11 States have the right for their nationals to engage in fishing on the high seas, subject (a) to their treaty obligations, (b) to the interests and rights of coastal States as proceed for in this Convention, (c) to the provisions contained in the following Articles concerning conservation of the living resources of the high seas.'

15 Fisheries Jurisdiction Case (United Kingdom v Iceland), [1974] ICJ Rep 3; Fisheries Jurisdiction Case (Germany v Iceland), [1973] ICJ Rep 3 [Fisheries Jurisdiction cases].

16 Ibid at para 64.

17 North Sea Continental Shelf Case (Germany v Netherlands), (Germany v Denmark), [1969] ICJ Rep 3 at 46-47, paras 83-85. 
also held that under the law of high seas fisheries, interested parties had a legal obligation to negotiate an equitable solution. ${ }^{18}$ The ICJ's decision relying on Article 2 of the 1958 Convention on the High Seas also informed the parties to the dispute to pay due regard to the interests of other states in the conservation and equitable exploitation of high seas fishing resources.

These decisions of international adjudicating bodies have served as precursors to the negotiations that eventually led to Part VII of the 1982 UN Convention on the Law of the Sea (UNCLOS), which refers to the legal regime of the high seas and, hence, the exercise of the freedoms within the context of this balance of rights, duties, and interests between states. ${ }^{19}$ In turn, the negotiators of UNCLOS eventually opted for the term 'due regard' to the interests of other states when qualifying high seas freedoms, an expression regularly referred to in international law as a manifestation of the obligation of good neighbourliness and the reasonable use of common resources. ${ }^{20}$ Various jurists opine that when it comes to the exercise of freedom of fishing, the application of 'reasonable use' means use that would not compromise other states' enjoyment of the same freedom. ${ }^{21}$ Their reasoning is consonant with Hugo Grotius's Mare Liberum work, wherein he identifies two main principles as the underlying basis for high seas freedoms: first, that the high seas are accessible to all and cannot be appropriated by any state and, second, that use of the sea and its resources by one state would leave the same available for use by another. ${ }^{22}$ Gilbert Gidel interprets these principles as both sides of the same coin: 'Dirigée contre l'exclusivité d'usage elle se résout nécessairement en une idée d'égalité d'usage. ${ }^{23}$

There seems to be consensus on this line of interpretation, ${ }^{24}$ but it is still considered difficult to put into practice what constitutes 'reasonable use,' 'non abuse of rights,' and 'equitable utilzation of resources. ${ }^{25}$ Unless a state is a

18 Fisheries Jurisdiction cases, supra note 15 at para 64.

19 UN Convention on the Law of the Sea, 21 ILM 1261 (1982) [UNCLOS].

20 E Hey, The Regime for the Exploitation of Transboundary Marine Fishery Resources, at 34-35 (1989). See also P Birnie, A Boyle, and C Redgwell, International Law and the Environment, at 201 (3rd edition, 2009).

21 R Bierzaneek, La Nature Juridique de La Haute Mer 2 RGDIP 245 (1895). See also MS McDougal and WT Burke, The Public Order of the Oceans, at 761-62 (1975). See also RJ Dupuys and D Vignes, A Handbook on the New Law of the Sea, volume 1, at 395 (1991). See also Birnie, Boyle, and Redgwell, supra note 20 at 201 and 204; Brownlie, supra note 1 at 225.

22 Hugo Grotius, Mare Liberum (1609), Chapter V. The book was republished and edited with an introductory note by James Brown Scott (1916).

23 Quoted in Brownlie, supra note 1 at 225.

24 F Orrego Vicuna, The Changing International Law of High Seas Fisheries, at 14 (1999); Birnie, Boyle, and Redgwell, supra note 20 at 201 and 204.

25 See Orrego Vicuna, supra note 24 , who says that it is difficult to put these principles of customary international law into practice, but it is wrong to assume that customary international law prosees for unrestricted freedom of fishing. See also Birnie, Boyle, and Redgwell, supra note 20 at 495, who argue that the tribunal in the Behring Sea case clearly recognized that the freedom of fishing was not absolute but had to be regulated to take reasonable account of the interests of other states, but they consider reasonableness as a basis that allows states to argue that its abuse affects their interests in a negative manner (at 201). The authors hold that the notion of reasonable use does not in itself serve as an 
party to an international agreement or considers that certain specific conservation measures are legally binding, the threshold beyond which the exercise of the freedom of fishing is deemed 'unreasonable' remains at the discretion of the high seas fishing state. ${ }^{26}$ In sum, it can be said that the international case law referred to earlier has served to provide sufficient evidence, which demonstrates that, although under international law the principle of freedom of fishing cannot be derogated from, it is a qualified right and does not entail uncontrolled or depredatory fishing activities. ${ }^{27}$ Nevertheless, international case law has not shed much light on the substantive content of these qualifications. Both the Behring Sea case as well as the Fishing Jurisdiction cases have highlighted the modus operandi that is allowed under international law for the parties to devise the substantive norms that would ultimately serve to achieve this balance of rights. Intrinsically, this should ensure that all states have access to living marine resources beyond national jurisdiction and the obligation to take the necessary measures for their conservation. In proposing this particular methodology to achieve these goals, the decisions of international adjudicating bodies have stressed the use of multilateral and regional co-operation instead of unilateralism.

2. The Freedom of Fishing and the Rights, Duties, and Interests of Coastal States The years following the Fishing Jurisdiction cases and the period when UNCLOS was being negotiated were characterized by the ever-increasing number of states that sought to extend coastal state jurisdiction as a measure to counter the rampant abuse of the freedom of fishing. The predominant trend was to extend coastal state maritime jurisdiction and encroach upon marine areas previously falling under the high seas regime, rather than concluding effective multilateral and regional fisheries agreements. A number of international disputes, namely the Application for Revision and Interpretation of the Judgment of 24 February 1982 in the Case Concerning the Continental Shelf (Tunisia v Libya), ${ }^{28}$ the Delimitation of the Maritime Boundary in the Gulf of Maine Area (Canada $v$ United States of America), ${ }^{29}$ and the Continental Shelf Case (Libya $v$ Malta), ${ }^{30}$ confirmed that the EEZ had become a rule of customary international law, a trend that has led to crucial and unprecedented legal developments under the international law of the sea, which has greatly influenced the

alternative rule of substantive law requiring sustainable use of resources. Similarly, the authors consider abuse of rights as setting the limits when states formulate certain international rights and obligations and that applying the doctrine outside this remit leads to instability and relativity in the application of international norms (at 205).

26 Dupuys and Vignes, supra note 21 at 399.

27 See Orrego Vicuna, supra note 24 at 22.

28 Application for Revision and Interpretation of the Judgment of 24 February 1982 in the Case Concerning the Continental Shelf (Tunisia v Libya), [1985] ICJ Rep 18.

29 Delimitation of the Maritime Boundary in the Gulf of Maine Area (Canada v United States of America), [1984] ICJ Rep 245.

30 Continental Shelf Case (Libya v Malta), [1982] ICJ Rep 12. 
relationship between coastal states and flag states whose nationals fish in those areas of the high seas adjacent to the EEZ.

Acquiescence by states to EEZ claims, or sometimes claims for an EFZ, has caused, under this new international regime, vast marine areas previously open to freedom of fishing to suddenly become part of the exclusive jurisdiction of coastal states - states that once had sovereign rights to exploit such species and the responsibility to ensure their conservation. The Fisheries Jurisdiction cases referred to the preferential rights of coastal states, which affected the balance between the rights of coastal states and flag states when the latter were fishing on the high seas. The EEZ regime gave coastal states 'sovereign rights' over living marine resources occurring therein. ${ }^{31}$ Furthermore, the negotiations that led to the conclusion of UNCLOS took into account the rights, duties, and interests of coastal states with an adjacent EEZ or EFZ when drafting the provisions regulating the freedom of fishing on the high seas. This fundamental legal development that was limitedly applied in the Fisheries Jurisdiction cases found itself as Article 116(b) in Part VII of UNCLOS. Part VII also entrenched the obligation on all flag states to co-operate as stakeholders in taking necessary conservation measures when fishing in the same areas of the high seas and for identical species. However, the establishment of the EEZ did not halt over-exploitation. In fact, the precarious state of the fisheries, and of the marine environment in general, continued to worsen years after many coastal states had made such a claim. The situation served to generate further disputes between states with an interest in the same fisheries. As explained earlier, although UNCLOS and the relevant case law had provided clear evidence that states had to co-operate to reach an agreement on how to adopt necessary conservation measures, the treaty did not establish any minimum standards that could apply until co-operation agreements were concluded. Neither did it establish a common denominator so as to determine what these 'necessary' conservation measures should include.

These shortcomings indicate why the most disputed provisions of UNCLOS, apart from the controversies surrounding its common heritage regime, were those relating to the conservation of straddling fish stocks and highly migratory species (HMS). States held disparate views as to how these provisions should be applied and implemented, both in the marine areas subject to coastal state jurisdiction and beyond. This state of play led to some highly emotional disagreements between states that threatened to upset the delicate balance of interests between coastal and high seas fishing states established under the convention. They also hampered the ultimate goal of ensuring adequate conservation for straddling stocks and HMS. A fully fledged dispute was the Fisheries Jurisdiction Case (Spain v Canada) (Estai case), which will mainly be dealt with in the next part of this article as it mainly brought to the fore the difficulties that hamper inspection and enforcement regimes on the high seas, even though

31 UNCLOS, supra note 19, Article 56(a). 
both Canada and Spain were parties to the same regional fisheries agreement, namely the North Atlantic Fisheries Organization (NAFO). ${ }^{32}$

Within the context of this part of the article, the decision in the Estai case corroborates the views held by the judges in the Behring Sea case, whereby the need to take conservation measures is not considered to constitute sufficient grounds to deny other states the right to access living marine resources in the adjacent areas of the high seas. The Estai case occurred in the same year that the final act of the UN Agreement for the Implementation of the Provisions of the United Nations Convention on the Law of the Sea of 10 December 1982 relating to the Conservation and Management of Straddling Fish Stocks and Highly Migratory Fish Stocks (Fish Stocks Agreement) was concluded and presented for signature. ${ }^{33}$ The Fish Stocks Agreement may be considered to be the international community's reaction to the difficulties exposed by state practice in trying to rely on the UNCLOS regime that left too much discretion in the hands of the stakeholders.

The 1992 United Nations Conference on Environment and Development had already proposed in Agenda 21 the imminent need for a multilateral agreement to promote the effective implementation of the applicable UNCLOS provisions on straddling stocks and HMS. ${ }^{34}$ The Fish Stocks Agreement, which adopts many of the sustainability objectives established under Chapter 17 of Agenda 21 , seeks to establish specific rules to address the conservation of straddling stocks and HMS on the high seas. It is termed to be an 'implementation agreement,' which is meant to supplement the UNCLOS legal framework by introducing new conservation concepts such as sustainable use, ${ }^{35}$ the precautionary approach, ${ }^{36}$ a broadened application of an ecosystem approach, ${ }^{37}$ compatibility between EEZ and high seas conservation measures, ${ }^{38}$ and placing additional weight upon the duty to co-operate. ${ }^{39}$ It provides the conservation measures that need to be taken if high seas fishing states and coastal states fail to reach an agreement, ${ }^{40}$ as required by UNCLOS in order to regulate the management and conservation of such stocks. ${ }^{41}$ The Fish Stocks Agreement also amplifies the conservation and management regime of $\mathrm{UNCLOS}^{42}$ as well as the other

\footnotetext{
32 Fisheries Jurisdiction Case (Spain v Canada), [1998] ICJ Rep 432 [Estai case].

33 Agreement for the Implementation of the Provisions of the United Nations Convention on the Law of the Sea of 10 December 1982 relating to the Conservation and Management of Straddling Fish Stocks and Highly Migratory Fish Stocks, 34 ILM 1547 (1995) [Fish Stocks Agreement].

34 Agenda 21 was adopted at the United Nations Conference on Environment and Development, Rio de Janeiro, 1992, <http://sustainabledevelopment.un.org/content/documents/Agenda21.pdf > .

35 Fish Stocks Agreement, supra note 33, Article 2.

36 Ibid, Article 5(c) and 6.

37 Ibid, Article 5(e), (f), (g) and also Article 8.

38 Ibid, Articles 5, 7, 8.

39 Ibid, Article 3(2) and Article 5.

40 Ibid, Part III.

41 UNCLOS, supra note 19, Article 63(2), 64(1).

42 Fish Stocks Agreement, supra note 33, Article 7(2).
} 
regional fisheries agreements addressing straddling stocks and HMS. ${ }^{43}$ It establishes the specific conservation duties of the flag states on the high seas ${ }^{44}$ as well as monitoring obligations to be taken by state parties as participants in a high seas fishery ${ }^{45}$ and as port states. ${ }^{46}$ All of these aspects will be further discussed in the next section of this article.

\section{Concluding Overview}

The selection of international jugdments referred to earlier influenced the formulation of new international norms as they identified evolving state practice in this field of international law. The case law under examination demonstrates that states consider their right of access over living resources on the high seas, as well as the non-appropriation of such resources by any state, as a general principle of international law-one of the high seas freedoms, more commonly known as the freedom of fishing. ${ }^{47}$ The adjudicators in the Behring Sea case, the Fisheries Jurisdiction cases, and the Estai case acknowledge that this freedom encompasses the right vested in the state, which allows fishing vessels registered under its flag to exploit living resources occurring beyond national jurisdiction. Other states cannot hinder it from exercising the freedom of fishing, but, in turn, the high seas fishing state has the concomitant duty not to restrict access to these same resources by other states.

Case law has also served to identify major developments in the interpretation of the application of freedom of fishing. The 'original' interpretation of a state's freedom of fishing as proposed by Grotius is based on arguments that date back to the time when the sustainability of stocks was not an issue of international concern. ${ }^{48}$ Over the centuries, as exploitation led to the scarcity of resources, some states pressed for the need to take conservation measures when fishing on the high seas - an obligation that, as explained earlier, was recognized as a concomitant duty to the freedom of fishing by the judges in the Behring Sea case. The 1958 Convention on the High Seas and Convention on Fish Conservation and Management on the High Seas reiterated the predominance of the freedom of fishing, but the judges in the Fisheries Jurisdiction cases, while affirming the freedom of access to high seas living resources, also accentuated the need to take conservation measures to safeguard the coastal state's interests over the same.

\footnotetext{
43 Some of the measures proposed by the Fish Stocks Agreement are based on those identified by UNCLOS and the fisheries agreements, but it also introduces new parameters that the 1982 UNCLOS merely refers to. For a detailed discussion on this topic, see S Borg, Conservation on the High Seas, Harmonizing International Regimes for the Sustainable Use of Living Resources, at 130-40 (2012).

44 Fish Stocks Agreement, supra note 33, Article 18.

45 Ibid, Article 20(6).

46 Ibid, Article 23.

47 See Brownlie, supra note 1 at 225, who quotes Gilbert Gidel, International Law Commission Yearbook, volume 2 at 68 and 252 (1950).

48 Grotius, supra note 22, Chapter V at 32 where Grotius says, 'the same principle which applies to navigation applies to fishing, namely it remains free and open to all.'
} 
The Fisheries Jurisdiction cases are considered to have greatly influenced the negotiations of UNCLOS, as this convention obligates states to exercise the freedoms with due regard to the rights of other states in their exercise of the same. ${ }^{49}$ It also establishes that states must ensure that their nationals take conservation measures when exercising the right of freedom of fishing on the high seas. ${ }^{50}$ These UNCLOS provisions are said to codify customary international law. They promote the exercise of the high seas' freedoms in a manner that ensures orderly access to such resources by others as well as the sustainability of stocks. ${ }^{51}$ UNCLOS clearly emphasizes what judges in the Fisheries Jurisdiction cases reiterated, namely that:

(a) The freedom of fishing as a norm of international law cannot be considered in isolation but should be applied in accordance with other basic international rules.

(b) The obligation to act with reasonable regard and to refrain from abuse of rights towards others who share the same rights. UNCLOS for instance refers mainly to the duty of flag states to cooperate with coastal states whose EEZ is adjacent ${ }^{52}$ to the high seas where exploitation takes place, and/or with other flag states that participate in the same high seas fishery. ${ }^{53}$

After the conclusion of UNCLOS in 1982, new international disputes highlighted the difficulties that ensued following the discretion that this convention allowed in the interpretation of the earlier provisions. The Estai case exposed the need to ensure compatibility of conservation measures between all states that participate in the exploitation of straddling stocks and HMS on the high seas and in the adjacent EEZ. The Fish Stocks Agreement, which entered into force a couple of years later, ${ }^{54}$ attempted to address the major contentious issues that characterize these disagreements between states. The Fish Stocks Agreement seeks to overcome the problem of non-adherence with existing regional and subregional fisheries agreements ${ }^{55}$ by establishing that its parties are to

49 UNCLOS, supra note 19, Article 87(2).

50 Ibid, Article 117.

51 For a brief historical account of the development of the law of the sea, see Brownlie, supra note 1 at 224-25; see also Birnie, Boyle, and Redgwell, supra note 20 at 706.

52 UNCLOS, supra note 19, Articles 116-20, Part VII, s 2 and the cross reference made in Article 116(b) to Articles 63(2) and 64-7.

53 Ibid, Article 118.

54 The Fish Stocks Agreement entered into force on 11 December 2001-that is, thirty days after the date of deposit of the thirtieth instrument of ratification or accession, in accordance with Article 40(1) of the agreement. The Estai decision was delivered by the ICJ in 1998. Negotiations leading to the Final Act of the Fish Stocks Agreement were concluded in 1995.

55 Examples include the 1950 Inter-American Tropical Tuna Commission; the 1969 International Commission for the Conservation of Atlantic Tunas; the 1979 North Atlantic Fisheries Organization; the 1982 Commission for the Conservation of Antartic Marine Living Resources; the 1994 Commission on the Conservation of the Southern Blue Fin Tuna; the 1995 Convention for the Conservation and Management of Pollock Resources in the Central Bering Sea, <http://www.afsc. 
comply with the conservation measures listed therein when fishing in high seas areas that fall under these agreements' jurisdictional scope. ${ }^{56}$ The Fish Stocks Agreement subsumes the conservation obligations in the regional and subregional fisheries agreements, ${ }^{57}$ and so all of its parties are legally bound to comply with them irrespective of whether they are parties or not to these agreements. ${ }^{58}$ There has been widespread adherence to the Fish Stocks Agreement, so compliance with the conservation measures laid down in regional and subregional fisheries agreements would have established, at least among the Fish Stocks Agreement parties, some uniformity and consistency when it comes to identifying which conservation measures are the ones that may be 'necessary' and, therefore, which 'flag states must ensure their nationals have to adopt when fishing on the high seas.' 59 Whether non-parties have acquiesced to this qualification as a concomitant obligation to the freedom of fishing, however, remains untested. Since the timing of the Estai decision and the conclusion of the Fish Stocks Agreement coincided, the Estai case could not provide the opportunity for the ICJ judges to verify whether the Fish Stocks Agreement provisions had also been acquiesced to as norms of customary international law.

\section{THE FLAG STATE'S EXCLUSIVE ENFORCEMENT JURISDICTION ON THE} HIGH SEAS

\section{Effectiveness of Flag State Jurisdiction and the 'Genuine Link'}

When Canada's navy officers arrested the crew and seized the Estai on the high seas in a NAFO regulatory area, ${ }^{60}$ the Spanish fishing vessel was allegedly fishing for straddling fish stocks in contravention of internationally agreed conservation and management measures. Spain argued that the Canadian Coastal Fisheries Protection Act (CFPA), on the basis of which the Canadian navy officers acted, was in breach of international law because it extended Canada's jurisdiction to board and inspect vessels on the high seas. ${ }^{61}$ The European Union (EU), which on behalf of Spain and its other member states was involved in the exchange of letters throughout the dispute, reiterated that the unilateral implementation of these provisions of the Canadian CFPA against the

noaa.gov/REFM/CBS/Docs/Convention\%20on\%20Conservation $\% 20$ of $\% 20$ Pollock\%20in\%20Centr al\%20Bering\%20Sea.pdf $>$; and the 1996 Indian Ocean Tuna Commission.

56 Fish Stocks Agreement, supra note 33, Article 8(3). For a map of the jurisdictional scope of the regional and subregional fisheries agreements, see E Meltzer, The Quest for Sustainable Fisheries, Regional Efforts to Implement the 1995 United Nations Fish Stocks Agreement, at 292-306 (2009).

57 Borg, supra note 43 at 37.

58 VCLT, supra note 2, Article 34 codifies a general principle of law, 'a treaty does not create either obligations or rights for a third state without its consent.'

59 UNCLOS, supra note 19, Article 117, which provides, 'All states have the duty to take, or to cooperate with other States in taking, such measures for their respective nationals as may be necessary for the conservation of the living resources of the high seas.'

60 Meltzer, supra note 56 at 292 for a map of the NAFO regulatory area.

61 Coastal Fisheries Protection Act, RSC 1985, c C-33. 
Estai undermined the efforts of the international community to achieve effective conservation through enhanced co-operation in the management of fisheries. Furthermore, Spain and the EU emphasized how Canada's actions on the high seas constituted a serious breach of international law, which went far beyond the question of fisheries conservation. Spain and the EU did not even attempt to prove that the Estai was not actually infringing conservation measures within an area of the high seas subject to NAFO and based their legal argument on the inviolability of flag state jurisdiction in exercising enforcement measures on the high seas. Spain and the EU insisted that a coastal state cannot board, inspect a vessel, and arrest the crew without the flag state's specific consent, as this constitutes a serious breach of international law. It is unfortunate that the court had to decline going into the merits of the case and ruled that it lacked the necessary jurisdiction to take cognizance of it. It appears, however, as is evident from Judge Oda's intervention, ${ }^{62}$ that the coastal state's need to take immediate action to enforce conservation measures, even if these were agreed to via a co-operation agreement, can never justify it for hindering other states from accessing living resources on the high seas. ${ }^{63}$

From a legal perspective, a positive outcome from the Estai case was the eventual compromise agreement reached between Canada and the EU, including Spain, on the implementation of conservation measures under NAFO. In a nutshell, this dispute saw, on the one hand, Canada amend its CFPA to renounce taking such enforcement measures against vessels flying the flags of other states without their consent, when the latter did not comply with conservation measures under the Canadian act. On the other hand, the EU member states had to take effective control to ensure that their vessels complied with such conservation measures. The two sides pledged that once either of them broke these two conditions such an agreement would be annulled. The Estai case demonstrated the dire need for concerted action to ensure a compatible, if not a uniform, approach towards the conservation of such species, wherever they occur. It was scientifically proven that in the case of straddling stocks and HMS the applicable international conservation regime must provide for co-ordination among stakeholder states such that measures adopted in one zone would not be undermined by the mismanagement of these species in another. This premise

\footnotetext{
62 He argued that the only issue in dispute, "was whether Canada violated the rule of international law by claiming and exercising fisheries jurisdiction (namely, the prescribing of fishery regulationsincluding the exclusion of fishing vessels flying the Spanish flag-the enforcement of those regulations by Canadian government authorities and the imposition of penal sanctions on a Spanish vessel and its master in an area of the high seas beyond the limit of its exclusive economic zone, or whether Canada was justified in exercising fisheries jurisdiction in that area, on the ground of its honestly held belief that the conservation of certain fish stocks was urgently required as a result of the fishery conservation crisis in the Northwest Atlantic-irrespective of the NAFO Convention, which neither provides for the unilateral adoption by coastal States of fishery regulations intended to apply in the Regulatory Area, nor entrusts coastal States with the enforcement of such regulations in that area of the high seas.'

63 See final judgment of the Estai case, supra note 32 at 478, para 7 (separate opinion of Judge Shigeru Oda). See also a discussion on this point by Borg, supra note 43 at 40-45.
} 
holds true for the appropriate conservation of all marine living resources, even if for obvious political and commercial reasons it is even more urgent for the international community to adopt such an approach when regulating the conservation of harvestable stocks that transcend maritime areas.

Abuse of, or ineffective, exclusive flag state jurisdiction on the high seas affects the conservation of living marine resources in two major ways. First, flag states that refuse to adhere to a co-operation agreement establishing uniform conservation measures that was adopted by other state participants in the same fishery cannot be coerced to approximate their position unless such measures have crystallized into customary international law. Consequently, a conservation regime applicable on the high seas that was painstakingly negotiated by a group of like-minded states may be jeopardized even if a minority, or indeed only one, flag state adopts weaker conservation obligations. Second, this situation may lead to flag hopping as owners of fishing vessels may choose to shop around and register their vessel with those flag states that have adopted weaker conservation measures. Furthermore, some flag states do not have the capacity or the political will to exercise their enforcement jurisdiction effectively when their fishing vessels conduct fishing operations on the high seas. The flag state has an obligation to ensure its nationals take conservation measures when exercising the freedom of fishing. Reference to nationals includes vessels registered under its flag. This phenomenon has led to international disputes that query what are the legal implications of the term 'genuine link,' which was a condition imposed by UNCLOS that must exist between the vessel and the flag state. ${ }^{64}$

UNCLOS elaborates upon the duties of the flag state in Article 94. Since its inception in the $1950 \mathrm{~s},{ }^{65}$ the legal interpretation of the term 'genuine link' has been riddled with controversy. ${ }^{66}$ During the negotiations of UNCLOS, the genuine link was not discussed at great length, ${ }^{67}$ and the states' perception of its legal interpretation, at the time, reflected the advisory opinion of the ICJ in the Constitution of the Maritime Safety Committee of the Inter-Governmental Maritime Consultative Organization. ${ }^{68}$ This advisory opinion, in turn, was

64 UNCLOS, supra note 19, Article 91.

65 Included as Article 5 of the 1958 United Nations Convention on the High Seas, supra note 12.

66 Brownlie, supra note 1 at 423; see also Judge Jennings remarks reprinted in 121 Hague Recueil 463 (1967) and International Law Commission's views in International Law Commission's Yearbook, volume 2 at 278-79 (1956).

67 The paragraph in the Main Trends Working Paper during the UNCLOS negotiations had adopted verbatim Article 5 of the 1958 Convention on the High Seas, supra note 12, and there were no proposals for an alternative text.

68 The advisory opinion of the ICJ in Constitution of the Maritime Safety Committee of the InterGovernmental Maritime Consultative Organization, [1960] ICJ Rep 23, has contributed to the shifting away from attempts to use the genuine link so as to limit reflagging of ships to open registries. It leans towards the need to ensure a genuine link by calling for the adoption of more stringent international norms for safety of ships and vessel-source pollution. 
based upon Article 5(1) of the 1958 Convention on the High Seas. ${ }^{69}$ There are, in fact, two main schools of legal thought under maritime international law that define the meaning of 'genuine link.' The restricted approach interprets the term to require that its nationals are either the owners, or are part of the crew, of those ships flying its flag. ${ }^{70}$ This approach has had limited success, mainly as a result of opposition from the traditional maritime states and states with open registries. ${ }^{71}$ Another interpretation examines the genuine link within its broader context, prescribing it for the sole purpose of safeguarding the necessary authority of the flag state in the best possible manner. ${ }^{72}$ According to this approach, the flag state's capacity to exercise its authority is essential, otherwise the concept of nationality of ships is futile and leads to anarchy on the high seas. ${ }^{73}$ This latter interpretation embodies, in a better manner, the concomitant duties that the flag states have with respect to ships flying their flag. Ultimately, it is the lack of control over vessels flying their flag that leads to the flag states' failure in securing compliance and enforcement of their international obligations during the exercise of their high seas freedoms.

The interpretation of a genuine link entailing effectiveness to secure compliance is also present in legal instruments regulating fishing vessels on the high seas where the debate on the meaning of 'genuine link' has also proved to be controversial. This was all too evident during the negotiations that led to the conclusion of the Food and Agriculture Organization's (FAO) Agreement to Promote Compliance with International Conservation and Management Measures by Fishing Vessels on the High Seas (Compliance Agreement). ${ }^{74}$ The Compliance Agreement did not adopt the wording of the Convention on the Conditions for the Registration of Ships (Registration Convention) with respect to the interpretation of the term. ${ }^{75}$ Neither did it include its qualification

69 'Each State shall fix the conditions for the grant of its nationality to ships, for the registration of ships in its territory, and for the right to fly its flag. Ships have the nationality of the State whose flag they are entitled to fly. There must exist a genuine link between the State and the ship; in particular, the State must effectively exercise its jurisdiction and control in administrative, technical and social matters over ships flying its flag.'

70 Brownlie, supra note 1 at 423-25. See also H Meyers, The Nationality of Ships, at 225 (1967).

71 Brownlie, supra note 1; see also McDougal and Burke, supra note 21 at 1008-140.

72 Ibid. See also Brownlie, supra note 1 at 425-28, n 20.

73 For a general discussion on the subject, see Meyers, supra note 70.

74 Agreement to Promote Compliance with International Conservation and Management Measures by Fishing Vessels on the High Seas, <http://sedac.ciesin.org/pidb/texts-menu.html > [Compliance Agreement]. It was concluded on 24 November 1993 and thus was negotiated later than the Convention on the Conditions for the Registration of Ships, Doc. TD/RS/CONF/19/Add.1 (7 February 1986) [Registration Convention]. A provision on the genuine link was originally included in a draft, but it was deleted when it became clear that its inclusion would jeopardize the timely finalization of the whole agreement.

75 The Registration Convention, supra note 74, which was negotiated between 1984 and 1986, attempted to elaborate the genuine link concept even further. The FAO Compliance Agreement, supra note 74, had attempted to address the act of reflagging. A draft of the agreement provided that Parties to it should refuse to register fishing vessels unless 'they had sufficient grounds to believe that the vessel would not be used to undermine the effectiveness of internationally agreed conservation 
as to what the level of national participation in ownership should be in order to ascertain this 'genuine link.' In this sense, unlike the Registration Convention, the FAO's Compliance Agreement has remained in line with UNCLOS's provision on the 'genuine link,' which neither refers to national participation nor does it distinguish between vessels used for fishing and other forms of shipping vessels. Therefore, despite the Registration Convention, the main trend is to interpret the term 'genuine link' as the flag state's capacity to control and exercise jurisdiction on the high seas, without going into the issue of 'sufficient national participation.' It appears that state practice favours this approach from the way international tribunals have addressed the issue.

The Court of Justice of the European Union (CJEU) examined the imposition of nationality requirements as an essential condition to guarantee a 'genuine link' in Anklagemyndigheden v Poulsen and Diva Navigation Corp Case. ${ }^{76}$ The court addressed the question whether member states of the European Community (EC) can maintain nationality requirements in respect of the registration of ships, as this would in turn discriminate against the freedom of movement of citizens of other member states. EU member states alleged that the imposition of such nationality requirements is an important instrument to ensure the existence of a 'genuine link' between the state and the ship. This case examined whether a vessel registered in a non-member country of the EC may be treated, for the purpose of Article 6(1)(b) of EEC Regulation 3094/86 Laying Down Certain Technical Measures for the Conservation of Fishery Resources, as a vessel with the nationality of a member state on the grounds that there is a 'genuine link' between it and the member state. ${ }^{77}$ The vessel concerned was owned and manned by Danish nationals and effectively operated from Denmark and had previously been registered in Denmark. In the Anklagemyndigheden case, the CJEU examined the 'genuine link' concept in the context of the legal order of the EC and also under international law. The CJEU held that, under international law, ${ }^{78}$ a vessel in principle has only one nationality, that of the state in which it is registered.

and management measures.' In addition, the original draft agreement contained a provision on the Allocation of the Flag (Article IV) on the genuine link which read: ' 1 . No Party shall accord any fishing vessel to which the Agreement applies the right to fly its flag unless it is satisfied, in accordance with its own national legislation, that there exists a genuine link between the vessel and the Party concerned. 2 (a) in determining whether or not there exists a genuine link for the purposes of paragraph 1, each Party shall give due weight to all relevant factors, including in particular:(i) the nationality or the permanent residence of the beneficial owner or owners of the vessel in accordance with their national law; (ii) where the effective control over activities of the vessel is exercised.' Despite the latitude of discretion, which this draft article left to the decision of the parties, it still managed to be considered too restricted and controversial and was left out from the final text.

76 Anklagemyndigheden v Poulsen and Diva Navigation Corp Case, C-286/90 [1992] ECR I-06019.

77 EEC Regulation 3094/86 Laying Down Certain Technical Measures for the Conservation of Fishery Resources, [1986] OJ L288.

78 It referred to Convention on the High Seas, supra note 12, Articles 5 and 6 and UNCLOS, supra note 19, Articles 91 and 92. 
In its decision, the CJEU found that, under international law, EU member states are not obliged to implement the 'genuine link' concept by imposing nationality requirements. It also found that a member state may not treat a vessel that is already registered in a non-member country, and therefore has the nationality of that country, as a vessel flying the flag of that member state. The fact that the sole link between a vessel and the flag state is the administrative formality of registration cannot prevent the application of that rule. The court held that it was for the state that conferred its nationality in the first place to determine, at its absolute discretion, the conditions on which it would grant its nationality. ${ }^{79}$

2. Strengthening the Role of Flag States and Options to Overcome Abuse In the $M / V$ Saiga Case (Saint Vincent and the Grenadines $v$ Guinea), the International Tribunal for the Law of the Sea (ITLOS) found that the absence of a genuine link does not give another state additional possibilities to take measures against a ship violating international norms and standards. ${ }^{80}$ The $M /$ $V$ Saiga was an oil tanker flying the flag of Saint Vincent and the Grenadines. It served as a bunkering vessel supplying fuel oil to fishing vessels and other vessels operating off the coast of Guinea. On 27 October 1997, the M/V Saiga crossed the maritime boundary between Guinea and Guinea Bissau and entered Guinea's EEZ where, on the 28 October 1997, it was arrested by Guinean customs patrol boats, taken into Conakry, Guinea, where the vessel and its crew were detained. No bond or other financial security was requested by Guinean authorities for the release of the vessel and its crew. Neither did Saint Vincent and the Grenadines offer to pay a bond. Instead, Saint Vincent and the Grenadines, as the flag state, instituted proceedings with ITLOS under Article 292 of UNCLOS.

Saint Vincent and the Grenadines argued that the tribunal should determine that the vessel, her cargo, and crew be released immediately without requiring that any bond be provided. It was prepared to provide any security reasonably imposed by the tribunal. Guinea, as the respondent state, requested the tribunal to dismiss the applicant's action. One of the claims made by the respondent state was an objection to admissibility on the grounds that there was no genuine link between the $M / V$ Saiga and Saint Vincent and the Grenadines. Guinea claimed that without

\footnotetext{
79 The court held that it follows from these considerations that the answer to the question must be that a vessel registered in a non-member country may not be treated, for the purpose of Article 6(1) (b) of EEC Regulation 3094/86, supra note 77, as a vessel with the nationality of a member state on the ground that it has a genuine link with that member state.

${ }^{80} \mathrm{M} / \mathrm{V}$ Saiga Case (Saint Vincent and the Grenadines $v$ Guinea) (Application for Provisional Measures), ITLOS Case 2 (1997) 37 ILM 360 (1998) [M/V Saiga case]. See also B Kwiatkowska, Inauguration of the ITLOS Jurisprudence: The Saint Vincent and the Grenadines v Guinea M/V Saiga Cases 30(1) ODIL 43 (1999).
} 
a genuine link between Saint Vincent and the Grenadines and the M/V 'Saiga,' the claim concerning a violation of its right of navigation and the status of the ship is not admissible before the Tribunal vis-à-vis Guinea, because Guinea is not bound to recognize the Vincentian nationality of the M/V 'Saiga,' which forms a prerequisite for the mentioned claim in international law. ${ }^{81}$

Guinea further argued that a state cannot fulfil its obligations as a flag state under UNCLOS with regard to a ship unless it exercises prescriptive and enforcement jurisdiction over the owner or the operator of the ship. Guinea insisted that there was no such relationship between the applicant and the said owner or operator of the $M / V$ Saiga and, therefore, that there was no 'genuine link' between the ship and Saint Vincent and the Grenadines. Consequently, it argued that it was not obliged to recognize the claims of Saint Vincent and the Grenadines in relation to the $M / V$ Saiga. Saint Vincent and the Grenadines strongly rebutted this claim of inadmissability. The tribunal addressed it on two fronts. It held that Article 91, paragraph 1, of UNCLOS provides that there must exist a genuine link between the state and the ship. The judges in this ITLOS decision held:

Two questions need to be addressed in this connection. The first is whether the absence of a genuine link between a flag State and a ship entitles another State to refuse to recognize the nationality of the ship. The second question is whether or not a genuine link existed between the Saiga and Saint Vincent and the Grenadines at the time of the incident. $^{82}$

The ITLOS judges went into the relationship of the 1958 Convention on the High Seas and the 1982 UNCLOS regarding the definition of the term 'genuine link.' They held that UNCLOS follows the approach of the 1958 convention, and the former's Article 91 retains the part of the third sentence of Article 5, paragraph 1 , of the 1958 convention, which provides that there must be a genuine link between the state and the ship. The other part of this sentence, stating that the 'flag State shall effectively exercise its jurisdiction and control in administrative, technical and social matters over ships flying its flag,' is reintroduced in Article 94 of UNCLOS as an instrinsic part of the duties of the flag state. The ITLOS decision established that, while the obligation regarding a 'genuine link' was maintained in the 1982 convention, the proposal that the existence of a 'genuine link' should be a basis for the recognition of nationality was not adopted. ${ }^{83}$

The ITLOS decision referred to the procedure to be followed where another state has "clear grounds to believe that proper jurisdiction and control with respect to a ship have not been exercised. ${ }^{84}$ This state is entitled to report the facts to the flag state, which is then obliged to 'investigate the matter and, if

81 M/V Saiga case, supra note 80 at para 75.

82 Ibid at para 79.

83 Ibid at para 81.

84 Ibid at para 6 
appropriate, take any action necessary to remedy the situation.' Furthermore, the tribunal's judges observed that nothing in Article 94 of UNCLOS permits a state that discovers evidence indicating the absence of proper jurisdiction and control by a flag state over a ship to refuse to recognize the right of the ship to fly the flag of the flag state. ${ }^{85}$ The conclusion of the judges sitting on the tribunal is that the purpose of the provisions of the convention on the need for a 'genuine link' between a ship and its flag state is to secure more effective implementation of the duties of the flag state and not to establish benchmarks against which the validity of the registration of ships in a flag state may be challenged by other states.

The ITLOS judges to this case, also referred to the Fish Stocks Agreement and the Compliance Agreement, which were not yet in force at the time. The judges held that even these agreements, 'set out, inter alia, detailed obligations to be discharged by the flag States of fishing vessels but do not deal with the conditions to be satisfied for the registration of fishing vessels.' 86 The tribunal therefore rejected the objection for inadmissibility, first, because there is no legal basis for Guinea's claim to refuse to recognize the right of the $M / V$ Saiga to fly the flag of Saint Vincent and the Grenadines. According to Guinea, there was no 'genuine link' between the ship. Second, the tribunal found that, in any case, the evidence provided by Guinea does not justify its contention that there was no 'genuine link' between the ship and Saint Vincent and the Grenadines at the time when the case happened. ${ }^{87}$ Therefore, the option of enhancing jurisdiction and control over fishing vessels by other interested parties can only apply when the flag state specifically consents to such an intervention by third parties.

The Estai case served to highlight the difficulties under international law relating to enforcement jurisdiction on the high seas, which is vested exclusively in the flag state. Presently, states that intervene upon non-party fishing vessels on the high seas without the flag state's consent, are considered to be in breach of international law for violating the exclusive jurisdiction of the flag state, even if they may be conducting illegal fishing operations. It is the flag state that has exclusive enforcement jurisdiction over its own fishing vessels on the high seas. Any exceptions to this rule may be exercised if specifically prescribed by treaties. ${ }^{88}$ In this context, boarding and inspection to check for compliance with conservation rules, if established by a treaty, are only applicable against state parties, and, as reiterated in the Estai case, the flag state's prior consent is still required in such cases.

85 Ibid at para 82

86 Ibid at para 85

87 Ibid at paras 87 and 88

88 Under international maritime law, one finds piracy jure gentium as an exception to the rule of exclusivity of flag state jurisdiction on the high seas in the sense that any state may assume jurisdiction over a vessel that carries out piractic acts on the high seas. This norm of customary international law is codified under UNCLOS, supra note 19, Article 105. 


\section{Concluding Overview}

The abuse of exclusive jurisdiction by flag states on the high seas is often linked to flags of convenience that remain a major hurdle for ensuring compliance with, and the enforcement of, conservation obligations in maritime areas falling outside national jurisdiction. The current position under international law as it emerges from the Anklagemyndigheden case and the $M / V$ Saiga case demonstrates that the lack of presence and control of the flag state over its vessels does not give the right to the coastal state to assume enforcement jurisdiction without the consent of the flag state. Inevitably, this situation does not facilitate the position of other states to curb flag state abuse. Various sources of international law referred to in the case law quoted earlier, tend to accept that the flag state's genuine link with the vessel manifests itself in its obligation to ensure effective jurisdiction and control over its vessels in order to secure compliance with conservation measures on the high seas. This is, after all, the real crunch issue since it is the absence of such control that leads to non-compliance and poor enforcement. The inability or inertia on the part of the flag state to secure compliance with, and enforcement of, international norms applicable on the high seas, stultifies regional co-operation on the conservation and management of marine living resources. Admittedly, national participation in ownership is an advantage for securing compliance, but it does not necessarily mean that to improve enforcement and eliminate illegal fishing the international community should rely upon nationality as a guarantee for better enforcement. States therefore have steered away from a more restrictive definition of the term 'genuine link,' particularly by avoiding the association of ownership with nationality requirements.

Following the position adopted by the case law referred to earlier, the Fish Stocks Agreement and various regional agreements proposed other measures to secure compliance with, and implementation of, international conservation regimes. ${ }^{89}$ They have done so mainly by elaborating in substantive terms the responsibilities of the flag state. ${ }^{90}$ Mandatory measures such as the granting of licenses or authorization to fish have been included in treaty provisions of the regional fisheries agreements. ${ }^{91}$ Some have established a procedure that renders the flag state accountable to the regional fisheries organization and interested state parties. ${ }^{92}$ The flag state is required to explain and defend its position with

\footnotetext{
89 See Borg, supra note 43 at 237-43, for a discussion on how the Fish Stocks Agreement, supra note 33, the Compliance Agreement, supra note 74, and regional fisheries management organizations have introduced limited jurisdiction to the 'inspecting state' and the port state that can intervene immediately and that may act in the absence of any measures that flag states should take but do not do so.

90 Compliance Agreement, supra note 74, Article III; Fish Stocks Agreement, supra note 33, Article 18 .

91 For a thorough overview of the regional and subregional fisheries agreements measures in this respect, see Borg, supra note 43 at 219-24; Meltzer, supra note 56 at 269-91.

92 Borg, supra note 43 at 226-34, for a detailed account of such procedures used by the different fisheries organizations and agreements.
} 
respect to enforcement measures taken against vessels flying their flag that have been in breach of conservation measures. In this manner, the international case law quoted earlier has served to guide states to devise legal mechanisms that guarantee the effective exercise of jurisdiction and control over fishing vessels instead of entering into the controversy raised by the 'genuine link' concept. This approach is not only a safer alternative, politically speaking, but also allows for more legal and practical flexibility.

Compliance measures can be varied to address the very different exigencies posed by fishing on the high seas. More importantly, widespread adherence to the Fish Stocks Agreement encourages port states to adopt strict sanctions on vessels with fish landings that have not been harvested on the high seas according to the convention's conservation regime. ${ }^{93}$ Similarly, coastal states (with the flag state's consent) may be allowed to exercise their enforcement powers upon foreign flag vessels. ${ }^{94}$ This would not only assist or supplement compliance by the flag state but may also help to discourage reflagging since fewer states would be in a position to offer a less rigorous conservation regime than the one imposed by the Fish Stocks Agreement. ${ }^{95}$ Even flag states that are reluctant to authorize port and coastal states to exercise controls over vessels flying their flag would at least be legally bound to act. ${ }^{96}$ At any rate, once the vessel voluntarily enters port it would be subject to the port state's regulations. It is only with respect to the exercise of criminal jurisdiction against the owners and the master of the vessel that the port state would remain dependant on the flag state's consent. $^{97}$

States can always apply the active nationality principle ${ }^{98}$ to counter reflagging, a measure also recommended in the FAO's International Plan of Action on Illegal, Unreported and Unregulated Fishing (IPOA-IUU). ${ }^{99}$ This international law principle enables states to exercise criminal jurisdiction over nationals wherever they fish, even if their fishing vessel is registered in another state. It must be acknowledged that even if states enact national legislation that inflicts criminal

93 International Maritime Organization (IMO), International Safety Management Code, IMO Resolution A.741(18), as amended by Docs MSC.104(73), MSC.179(79), MSC.195(80) and MSC.273(85), <http://www.imo.org/OurWork/HumanElement/safetymanagement/pages/ismcode. aspx $>$. The success of regional co-operation in controlling and enforcing maritime conventions under the Paris Memorandum of Port State Control has led to the adoption of this approach for other regions in recent years. The Paris Memorandum itself has been amended several times to enhance its effectiveness.

94 See Convention on the Conservation of Antarctic Marine Living Resources, 19 ILM 841 (1980), Article V; Western and Central Pacific Fisheries Commission, Article 26. For a detailed discussion, see Borg, supra note 43 at $237-42$.

95 Fish Stocks Agreement, supra note 33, Article 19(1)(e).

96 Ibid, Article 23.

97 Brownlie, supra note 1 at 318-19.

98 Ibid at 303-4.

99 International Plan of Action on Illegal, Unreported and Unregulated Fishing, in Responsibilities of All States, at 6; the IPOA refers to controls over nationals and national legislation providing for enforcement in the case of illegal, unreported, and unregulated fishing. 
punishment upon the owners and crew of ships that permit and use illegal fishing gear, exploit protected species, or carry out any other illegal activity related to fishing on the high seas, effective enforcement in such cases remains unlikely due to this lack of 'presence.' Furthermore, the way states apply the active nationality principle varies and is often limited in many ways. Few states have a legal framework that bestows upon them jurisdiction over their nationals under any circumstances, wherever these nationals would be. ${ }^{100}$ It is therefore unlikely that this legal remedy would spur flag states that do not have the will or the capacity to control their vessels to take action via the active nationality principle.

\section{THE ECOSYSTEM APPROACH AND THE LEGAL STATUS OF LIVING MARINE} RESOURCES IN AREAS BEYOND NATIONAL JURISDICTION

\section{The Meaning of ‘Conservation’ of Living Marine Resources and Its Evolution} under International Law

Since the creation of UNCLOS, new conservation principles have evolved proposing a wider scope to the obligation to take conservation measures on the high seas that is not limited to safeguarding the balance of interests solely between states directly involved in fisheries. The ecosytem approach qualifies the freedom of fishing even further, aiming at conserving marine biodiversity in its entirety and the oceans as a single habitat for the benefit of all states in the interest of both present and future generations. Similarly, the precautionary approach requires states to avoid risks and choose more selective harvesting methods and less intensive fishing efforts. ${ }^{101}$ Agreeing upon a legal definition of the term 'conservation' and the scope of its applicability is one of the major challenges during the course of negotiating a fisheries treaty. ${ }^{102}$ In other words, which benchmarks should the international community use to translate the obligation to take conservation measures into substantive legal provisions? Should conservation measures be limited only to harvestable species or should they

100 This is in fact what the United States can do under the Lacey Act, which provides US enforcement officials with authority to prosecute vessels and fishermen in the United States for violating any fishery regulations of any state wherever the vessel is and wherever the offence was committed. See also Riddle Kevin, IUU Fishing: Is International Cooperation Contagious? 37(3-4) ODIL 272 (2006).

101 See, for example, Fish Stocks Agreement, supra note 33, Article 6(1), which establishes that the precautionary approach that should be applied widely for the purpose of, "conservation, management and exploitation of straddling fish stocks and highly migratory fish stocks in order to protect the living marine resources and preserve the marine environment.'

102 C De Klemm, Living Resources of the Oceans, in DM Johnson, ed, The Environmental Law of the Sea, IUCN Environmental Policy Paper no 18, 71 at 118 (1981), who remarks that it is ironic that international law insisted on relying on the maximum sustainable yield despite the skepticism surrounding the validity and accuracy of the concept for achieving a favourable conservation status. See also WT Burke, The New International Law of Fisheries, UNCLOS and Beyond, at 45-55 (1994); Borg, supra note 43 at $177-78$. 
ensure the conservation of the entire ecosystem and habitat of the species subject to exploitation?

The High Seas Fishing Convention provides one of the very few definitions of the term 'conservation' as 'an aggregate of measures rendering possible an optimum sustainable yield so as to serve a maximum supply of local food and other marine products.' ${ }^{\prime 03}$ This convention establishes that conservation programs should be formulated to secure food for human consumption and products for their needs. The insistence on anthropocentric requirements as a basis for conservation under the convention did not leave much room for interpreting the term according to the ecocentric approach and for exploring the wider interest of the international community in the same resources. A few years later, as the 1982 UNCLOS negotiations were still in full swing, the ICJ judges in the Fisheries Jursidiction cases departed from the interpretation of the term 'conservation' as defined by the unsuccessful 1958 High Seas Fishing Convention. After assessing other applicable fisheries conventions ${ }^{104}$ and state practice at the time, the judges held that

it is one of the advances of maritime international law, resulting from the intensification of fishing, that the former laissez-faire treatment of living resources of the high seas has been replaced by a recognition of a duty to have due regard to the rights of other States and the needs of conservation for the benefit of all. ${ }^{105}$

According to the ICJ's decision, the definition of conservation provided in the High Seas Fishing Convention seems to have evolved to include the flag state's duty as an obligation intended for the benefit of all states and not only to safeguard the preferential rights of coastal states adjacent to the high seas and other flag state participants to a fishery. ${ }^{106}$ These views of the ICJ in the Fisheries Jurisdiction cases were, as already discussed earlier, ${ }^{107}$ to some extent later reflected in UNCLOS's definition of freedom of fishing and the obligation to exercise the freedoms with due regard to the interests of other states. ${ }^{108}$ Another relevant measure includes Article 119(b), which provides that when taking conservation measures during fishing operations on the high seas, flag states shall 'take into consideration the effects on species associated with or dependent upon harvested species.' The drafters of UNCLOS chose not to define conservation and sought to qualify the freedom of fishing by imposing an obligation upon all states exercising such a right to take the necessary conservation measures when their nationals exploit living marine resources on the high seas. ${ }^{109}$ States are

103 High Seas Fishing Convention, supra note 14, Article 2.

104 See list in note 55 in this article.

105 Fisheries Jurisdiction cases, supra note 15 at para 64.

106 See also Orrego Vicuna, supra note 24 at 10; Oda Shigeru, International Control of Sea Resources, at xxvi (1989).

107 See discussion earlier in this article

108 UNCLOS, supra note 19, Article 87(2).

109 Ibid, Article 117. 
required to do so not only in the case of harvestable species but also for related and dependant living marine resources. ${ }^{110}$ The convention's provisions, however, do not enter into the specifics, and so a myriad of other international agreements, drawn up in different fora, establish various norms that seek to translate into substantive terms the major legal developments referred to earlier, while balancing out the diverse interests of the various states and the ecological requirements of marine species and their habitat.

These agreements can be divided into three main categories: fisheries agreements, ${ }^{111}$ multilateral environmental agreements (MEAs), ${ }^{112}$ and regional seas programs, ${ }^{113}$ which in most cases have a legal component that includes a convention and various protocols issued thereunder. More than 143 countries participate in thirteen regional seas programs established under the auspices of the UN Environment Programme in major maritime regions. ${ }^{114}$ The Fish Stocks Agreement was the first serious attempt to approximate the ultimate goals and objectives of the international fisheries regimes with those of MEAs and other sources of international environmental law. The Fish Stocks Agreement and the Convention on Biological Diversity (CBD) also influenced other regional and subregional fisheries agreements and regional seas programs to revise their constituent treaties and incorporate more holistic conservation goals. ${ }^{115}$ These trends, which favour an ecosystem approach, highlight the international community's awareness of the intrinsic value of all living marine resources and their habitat. 116

110 Ibid, Article 119.

111 The 1946 International Convention for the Regulation of Whaling (ICRW); the 1950 InterAmerican Tropical Tuna Commission; the 1969 International Commission for the Conservation of Atlantic Tunas; the 1979 North Atlantic Fisheries Organization; the 1982 Commission for the Conservation of Antartic Marine Living Resources; the 1993 FAO Compliance Agreement, supra note 74; the 1994 Commission on the Conservation of the Southern Blue Fin Tuna; the 1995 Convention for the Conservation and Management of Pollock Resources in the Central Behring Sea; the 1996 Indian Ocean Tuna Commission; the 1995 Fish Stocks Agreement, supra note 33; the 1997 General Fisheries Commission for the Mediterranean; the 2003 Convention on the Conservation and Management of Fishery Resources in the South East Atlantic Ocean; and the 2004 Western and Central Pacific Fisheries Commission.

112 The following are major multilateral environmental agreements (MEAs) that also address the conservation of living marine resources. The earliest examples include the 1973 Convention on International Trade in Endangered Species of Wild Flora and Fauna, 12 ILM 1088 (1973) [CITES], and the 1979 Convention on the Migratory Species of Wild Animals, 19 ILM 15 (1980) [CMS]. More recent MEAs include the 1992 Convention on Biological Diversity, 31 ILM 818 (1992) [CBD]; the 1995 Agreement on the International Dolphin Conservation Programme, [1999] OJ L132.

113 The Regional Seas Programme was launched in 1974. Ecosystems and biodiversity are a key issue addressed by these programs. See <http://www.unep.org/regionalseas/issues/default.asp $>$.

114 The regions covered are: the Black Sea, Wider Caribbean, East Asian Seas, Eastern Africa, South Asian Seas, ROPME Sea Area, which involves the Arabian Gulf States, Mediterranean, North-East Pacific, Northwest Pacific, Red Sea and Gulf of Aden, South-East Pacific, Pacific, and Western Africa. There are also five partner programs for the Antarctic, Arctic, Baltic Sea, Caspian Sea, and north-east Atlantic regions.

115 Meltzer, supra note 56, for matrices; Borg, supra note 43 at 182-87. CBD, supra note 112.

116 Birnie, Boyle, and Redgwell, supra note 20 at 128-32. 
Apart from favouring, albeit rather cautiously, an ecosystem approach, general state practice has clearly supported the need for formulating special conservation measures for particular marine species such as straddling stocks, sedentary species, and marine mammals. While the Behring Sea case has subjected seals (marine mammals) to the same regime as other living marine resources ever since the mid-twentieth century, the trend is to distinguish between marine mammals and other harvestable marine living resources.

\section{Conservation as an Obligation Erga Omnes}

The ecosystem approach implies that all marine biodiversity has an intrinsic value per se. This line of reasoning may also imply the right of any state to make a claim against another that has failed to take 'necessary conservation measures on the high seas.' These arguments also serve to highlight a link between the resources vested in humanity as a whole and erga omnes obligations under international law. In Barcelona Traction, Light and Power Company (Belgium $v$ Spain), the ICJ distinguished between two different types of obligations that states may have, namely contractual obligations that arise vis-á-vis only those states with whom they may have concluded an agreement and erga omnes obligations whose binding effect is collective and owed to the international community as a whole. ${ }^{117}$ The issue of erga omnes obligations in an environmental context was raised in the 1974 Nuclear Tests Cases (Australia v France and New Zealand $v$ France) when Australia and New Zealand complained that nuclear experiments by France in marine areas beyond national jurisdiction constituted an interference with the high seas' freedoms of all states. ${ }^{118}$ In this case, the ICJ did not accept that Australia and New Zealand had the required legal standing to bring forward such a claim against France and so dismissed the applicability of the erga omnes obligation in this context.

Recent developments brought about by the evolution of international environmental law may have led the international adjudicating body to adopt a different stand today. For instance, the CBD in its preamble has classified biological diversity as a common concern of humankind. ${ }^{119} \mathrm{By}$ 'affirming that the conservation of biological diversity is a common concern of humankind,' the parties to the CBD consider biodiversity, including living marine resources, as a common resource whose vulnerability requires a concerted effort from all states to ensure its conservation for present and future generations. ${ }^{120}$ So far the 'common concern concept' is included only in UN resolutions and preambular

117 Barcelona Traction, Light and Power Company (Belgium v Spain, [1970] ICJ Rep 3.

118 Nuclear Tests (Australia v France) (Jurisdiction), [1974] ICJ Rep 253; Nuclear Tests (New Zealand v France) (Jurisdiction), [1974] ICJ Rep 457.

119 CBD, supra note 112 at preamble para 3.

120 FL Kirgis Jr, Standing to Challenge Human Endeavours That Could Change the Climate 84 AJIL 525 (1990). See also Birnie, Boyle, and Redgwell, supra note 20 at 128-32; Alan Boyle, International Law and Protection of the Global Atmosphere: Concepts, Categories and Principles, in RR Churchill and D Freestone, eds, International Law and Global Climate Change, 7 (1991). 
paragraphs in treaties, ${ }^{121}$ but it may serve to strengthen the legal standing of a state to make a claim against another state that has failed to adopt conservation measures to safeguard a common resource, even if it is not directly affected as a coastal state or as a participant in the same high seas fishery. In their Draft Articles on the Responsibility of States for Internationally Wrongful Acts, the members of the International Law Commission (ILC) have included the possibility of legal standing by states, other than the injured state, when the obligation breached is, 'owed to a group of states, including that state and is established for the protection of the collective interest of the group' 122 and/or 'if the obligation breached is owed to humanity as a whole. ${ }^{123}$ In their commentary to these articles, the ILC refers to 'the environment' as an example of the first type of obligation and protection from marine pollution as an example of the second. ${ }^{124}$

It is useful to examine any legal implications the notion of common concern may have upon future decisions of the ICJ or other international adjudicating bodies, bearing in mind the commentaries made by the ILC and the recognition by the state parties to the CBD regarding the precarious state of natural resources such as biological diversity. ${ }^{125}$ By declaring in the preamble of the CBD that biodiversity is a common concern of humankind, the parties acknowledge the limitations of regulating such resources only on the basis of jurisdictional zones. The CBD refers to the jurisdictional scope of the treaty and includes 'processes and activities, regardless of where their effects occur, carried out under the jurisdiction or control of contracting Parties, within the area of its national jurisdiction or beyond the limits of national jurisdiction.' ${ }^{126}$ The CBD is not subjecting living resources on the high seas to global management as UNCLOS does with the mineral resources of the deep seabed under Part XI. The parties, by affirming biological diversity as a common concern of humankind in view of the jurisdictional scope of the same treaty, as identified in Article 4(b), imply that because of their particular nature and importance, components of biodiversity

121 The concept was originally put forward in UNGA Resolution 43/53 on Climate Change, was then incorporated in the preambular paragraphs of both the United Nations Framework Convention on Climate Change, 31 ILM 849 (1992) [UNFCCC], and the CBD, supra note 112.

122 ILC Draft Articles on Responsibility of States for Internationally Wrongful Acts with Commentaries, reprinted in Report of the International Law Commission on the Work of its FiftyThird Session (2001), Article 48(1)(a), 126 et seq.

123 Ibid, Article 48(1)(b).

124 Ibid, commentaries to Article 48(1)(b) at 127.

125 The concept was first proposed by Malta under UNGA Resolution 43/53 as the first paragraph of this resolution that may be considered as the genesis of the UNFCCC, supra note 121. The legal implications of the phrase reported here were explained in the second committee by David Attard, chief legal adviser to the Malta delegation at the time. The same phrase was later adopted to define the status of biological diversity under the CBD, supra note 112 .

126 CBD, supra note note 112, Article 4(a) and (b). The provisions of the CBD apply in relation to each contracting party: '(a) In the case of components of biological diversity, in areas within the limits of its national jurisdiction; to the contracting Parties with respect to the components of biodiversity. In para 4 of the preamble and article 3 of the CBD the host State has sovereign rights over such biodiversity located within those areas subject to its jurisdiction.' 
(including those occurring on the high seas) are of vital interest to humankind and constitute a global unity. Any threats to their conservation status may affect the whole community of states or humanity as a whole.

The possibility that the conservation of high seas living resources may be considered by states as an erga omnes obligation may also be inferred from Judge Christopher Weermantry's dissenting opinion in Gabčíkovo-Nagymaros Project (Hungary/Slovakia), which was given after the conclusion of the CBD. ${ }^{127}$ This case was the first international dispute of a purely environmental nature that the ICJ had to decide upon. Judge Weeramantry referred to sustainable development as an erga omnes obligation. ${ }^{128}$ Given the assimilation that conservation has assumed with sustainable development and sustainable use, ${ }^{129}$ and compared to the maximum sustainable yield levels prescribed by the applicable provisions of UNCLOS, ${ }^{130}$ this dissenting opinion has strengthened the arguments made earlier regarding the apparent trend to subject resources of global significance to the international community's legitimate interest to safeguard them and impose upon all states a common responsibility to ensure their sustainable use. More recently in Pulp Mills on the River Uruguay (Argentina $v$ Uruguay), the ICJ was asked to settle a dispute between Argentina and Uruguay after Uruguay unilaterally decided to build two pulp mills on the river that serves as a border between the two states. ${ }^{131}$ The Pulp Mills case involved transboundary pollution and not over-exploitation as a form of environmental degradation. It also related to a shared, rather than a common, resource such as the high seas.

The ICJ decision in the Pulp Mills case, however, may shed further light on the validity of the arguments made earlier and on the possible line of thinking that an international tribunal may take if it has to decide a dispute involving the legal standing of any state to challenge another state's over-exploitation of living resources on the high seas. ${ }^{132}$ Relying on the advisory opinion it had given in 1996 in Legality of the Threat or Use of Nuclear Weapons, the ICJ's judgment in the Pulp Mills case held: 'A State is thus obliged to use all the means at its disposal in order to avoid activities which take place in its territory, or in any area under its jurisdiction, causing significant damage to the environment of

127 Gabčíkovo-Nagymaros Project (Hungary/Slovakia), [1997] ICJ Rep 7.

128 Ibid. See also Birnie, Boyle, and Redgwell, supra note 20 at 131, n 153, who argue that the assumption that sustainable development is a legal obligation may be incorrect. Brownlie, supra note 1 at 278 , refers to sustainable development as an 'emergent principle of international law.'

129 See also Borg, supra note 43 at 175-79.

130 UNCLOS, supra note 19, Article 119.

131 Pulp Mills on the River Uruguay (Argentina v Uruguay) (Provisional Measures), [2006] ICJ Rep 113.

132 D Tladi, Principles of Sustainable Development in the Case Concerning the Pulp Mills on the River Uruguay, Legal Working Paper for the International Development Law Organization (2002), $<$ http://www.idlo.int/Documents/Rio/01.\%20Pulp\%20Mills\%20on\%20the\%20River\%20Uruguay. pdf>. See also A Boyle, Pulp Mills Case: A Commentary, < http://www.biicl.org/files/5167_pulp_ mills_case.pdf $>$. 
another State. ${ }^{133}$ The judgment went on to say that this obligation 'is now part of the corpus of international law relating to the environment.'

An international case that could have specifically determined whether under international law a state can bring forward an international claim regarding the over-exploitation of a common resource, without the applicant having to prove a direct interest, was Whaling in the Antarctic (Australia v Japan). ${ }^{134}$ Australia instituted legal proceedings against Japan before the ICJ, where it alleged that Japan had breached, and is continuing to breach, the obligation under paragraph 10(e) of the International Convention for the Regulation of Whaling's schedule to observe the zero catch limit in relation to the killing of whales for commercial purposes. ${ }^{135}$ It also alleged a breach by the respondent of its obligation under paragraph 7(b) to act in good faith and refrain from undertaking commercial whaling of humpback and fin whales in the Southern Ocean Sanctuary. Japan, as the respondent, claimed that it was not breaching the moratorium but, rather, availing itself of whaling conducted under Article VIII, commonly referred to as 'special permit' or 'scientific' whaling. ${ }^{136}$ Australia rebutted these claims and additionally asserted that Japan, by carrying out its research whaling program in the Southern Ocean, referred to as the JARPA II program, had breached its obligations under the Convention on International Trade in Endangered Species of Wild Fauna and Flora (CITES) with respect to the proposed take of humpback whales. ${ }^{137}$ Australia also argued that Japan was in breach of the CBD where, as a party, it is required to ensure that activities under its jurisdiction and control do not cause damage to the environment of other states or areas beyond the limits of national jurisdiction. Australia requested the ICJ to order Japan to cease the implementation of the JARPA II program, to revoke any authorizations, permits, or licenses, and provide assurances that it would guarantee that any further action under JARPA II or similar programs be brought into conformity with international law. Eventually during the course of the proceedings, Japan decided to stop its JARPA II program in the Southern Ocean, and so the case has been closed. We will never know whether the ICJ would have

\footnotetext{
133 Legality of the Threat or Use of Nuclear Weapons, [1996] ICJ Rep 242, para 29.

134 Whaling in the Antarctic (Australia v Japan), [2010] ICJ Rep 400. See article by DR Rothwell, Australia v. Japan: JARPA II Whaling Case before the International Court of Justice, in Proceedings Instituted by Australia against Japan: Application Instituting Proceedings (31 May 2010). See also Reuben B Ackerman, Japanese Whaling in the Pacific Ocean: Defiance of International Whaling Norms in the Name of 'Scientific Research,' Culture, and Tradition 25 BC Int'1 \& Comp L Rev 323 (2002); E Merron, The Regulation of International Whaling: Will Australia v. Japan Mark a Turning Point? Mich J Envt'l \& Administrative L (4 December 2012), <http://students.law.umich.edu/mjeal/ 2012/12/the-regulation-of-international-whaling-will-australia-v-japan-mark-a-turning-point $>$.

135 International Convention for the Regulation of Whaling, 161 UNTS 72 [ICRW].

136 Ibid, Article VIII, provides that 'any Contracting Government may grant to any of its nationals a special permit authorizing that national to kill, take and treat whales for purposes of scientific research ... . and the killing, taking and treating of whales in accordance with the provisions of this Article shall be exempt from the operation of this Convention.'

137 CITES, supra note 112 .
} 
accepted Australia's legal standing to institute such proceedings on behalf of the international community as a whole.

\section{Concluding Overview}

The increase in public awareness on the precarious state of living resources on the high seas has nurtured a strong political will to consider the oceans as a holistic ecosystem where all species and their habitat have to be safeguarded from anthropogenic interference and mismanagement. Consequently, towards the end of the twentieth century, the objective of applicable norms became more focused on ensuring the conservation of living marine resources via their sustainable use, wherever they occur and irrespective of whether they are harvestable or not. Freedom of fishing remains a prima facie right vested in all states, and, as reiterated earlier, the exclusive rights of coastal states in their economic or fishing zones are acquiesced to as a norm of customary international law. Both of these rights were enshrined in UNCLOS.

The more recent trends in legal thinking, particularly in light of the ILC's draft articles, suggest that while a common resource cannot be appropriated global responsibilities towards it may become erga omnes in character, owed to the international community as a whole. Under these circumstances, any state would have the legal standing to make an international claim against another, for lack of compliance with an erga omnes obligation under international law. To date, apart from the dissenting opinion of Judge Weermantry who refers to sustainable development as an erga omnes obligation in the GabčíkovoNagymaros case, the ICJ has not applied the concept of erga omnes obligations outside human rights or humanitarian law. The CBD's substantive obligations, which establish that states shall ensure that any activities falling under their authority in areas beyond national jurisdiction must comply with the provisions of the same convention, tend to pave the way forward for further developments, according to this trend in the line of legal thinking. ${ }^{138}$

\section{THE ROLE OF ADJUDICATING BODIES FOR THE HARMONIZATION OF}

\section{APPLICABLE NORMS}

\section{Harmonization of Successive and Specialized Norms}

One of the major challenges international adjudicating bodies face when resolving disputes between states is the fragmented nature of international law. The report of the ILC's study group, entitled Diversification and Expansion of International Law: Difficulties Arising from Diversification and Expansion of International Law, refers to the harmonization of norms as a legal technique to overcome fragmentation via the systematic integration of various sources of international law that may be applied in the circumstances. The same report

138 Birnie, Boyle, and Redgwell, supra note 20 at 232-33. 
identifies applicable international norms regulating the conservation of marine living resources on the high seas to be one of the primary examples of fragmentation under international law. ${ }^{139}$ Both international fisheries agreements and some MEAs ${ }^{140}$ have addressed the conservation of living resources on the high seas, but, since they developed in parallel, ${ }^{141}$ the two streams of international law have adopted different strategies, standards, and rules to regulate these same goals. Fragmentation may give rise to normative conflicts when two or more treaties or other sources regulate the same situation. ${ }^{142}$ For instance, the 1958 High Seas Fishing Convention defines conservation and perceives it as a measure to ensure food security. The Convention on the Migratory Species of Wild Animals, whose scope of applicability also includes living marine marine resources, provides a very detailed definition of conservation that goes beyond the anthropocentric approach found in the 1958 High Seas Fishing Convention. ${ }^{143}$ UNCLOS does not define conservation and establishes the obligation to take conservation measures when states exercise the freedom of fishing not only with respect to harvestable living resources but also for 'associated or dependent species.' 144

More recent treaties such as the 1992 CBD and the 1995 Fish Stocks Convention aim at the conservation of the species per se and have formulated detailed obligations on how conservation measures should be implemented. The CBD's provisions lay down conservation obligations applicable to all forms of biodiversity when state parties carry out operations under their jurisdiction on the high seas, ${ }^{145}$ while the Fish Stocks Agreement's jurisdictional scope is focused on straddling stocks and HMS. These examples demonstrate that in

139 Diversification and Expansion, supra note 9, para 1-4.

140 For a list of fisheries agreements and MEAs, see notes 111 and 112 in this article respectively

141 See Birnie, Boyle, and Redgwell, supra note 20 at 744-52; Borg, supra note 43 at 14-16.

142 According to the wording of Article 38 of the ICJ Statute, if there is an apparent or an actual conflict between treaty and custom, the general trend is that the treaty provisions will prevail, whenever both states involved in the dispute are parties to the same treaty. For a discussion on conflict of norms under International law. See Pauwelyn, supra note 3.

143 CMS, supra note 112, Article 1(b), (c) and (d), which defines the conservation status of a migratory species as 'the sum of the influences acting on the migratory species that may affect its long-term distribution and abundance.' According to the convention, the 'conservation status' will be taken as 'favourable' when '(1) population dynamics data indicate that the migratory species is maintaining itself on a long-term basis as a viable component of its ecosystems; (2) the range of the migratory species is neither currently being reduced, nor is likely to be reduced, on a long-term basis; (3) there is, and will be in the foreseeable future, sufficient habitat to maintain the population of the migratory species on a long-term basis; and (4) the distribution and abundance of the migratory species approach historic coverage and levels to the extent that potentially suitable ecosystems exist and to the extent consistent with wise wildlife management; and (d) 'Conservation status' will be taken as 'unfavourable' if any of the conditions set out in sub-paragraph (c) of this paragraph is not met.'

144 UNCLOS, supra note 19, Article 119(1)(b).

$145 \mathrm{CBD}$, supra note 112, Article 4: 'The provisions of this Convention apply, in relation to each Contracting Party: ... (b) In the case of processes and activities, regardless of where their effects occur, carried out under its jurisdiction or control, within the area of its national jurisdiction or beyond the limits of national jurisdiction.' 
the compendium of international norms that regulate the conservation of living resources on the high seas, one finds examples of lex priori and lex posteriori as well as lex generalis and lex specialis. This situation complicates the position of users as they need to discern what their legal obligations are amid this plurality of applicable norms. The 1969 Vienna Convention on the Law of Treaties (VCLT) is considered to be an authoritative source on the law of treaties, ${ }^{146}$ incorporating some general principles of law. ${ }^{147}$ It establishes that state parties shall take into account 'any relevant rules of international law applicable in the relations between the parties. ${ }^{148}$ This quotation implies that there is a presumption against conflict when the same set of facts may be regulated by more than one treaty and that users must aim for the harmonization of applicable norms when they interpret treaties accordingly.

In the case of lex priori and lex posteriori, Article 30 of the VCLT provides that if 'successive treaties relate to the same subject-matter' a subsequent treaty that specifies that it is subject to an earlier treaty and/or not in conflict with it should be interpreted to mean that the provisions of the earlier treaty 'shall prevail.' This provision explains why Article 311(1) of UNCLOS establishes that it should prevail over the 1958 Convention on the High Sea and the 1958 High Seas Fishing Convention among state parties. If a treaty is not suspended, although it has been replaced by another, it remains applicable vis-à-vis those states that are parties to it and that are also parties to the new treaty, insofar as it does not conflict with the provisions of the latter. The provisions of the earlier treaty would, however, still prevail if, in the case of a dispute where it is applied, one of the states is a party to it but not to the new treaty. The use of certain terminology in treaties such as 'without prejudice to' and 'further to' are often utilized to overcome the potentially conflicting interpretation of subsequent treaties vis-à-vis the previous one. Article 22 of the CBD and Article 311 of UNCLOS take this situation into consideration. ${ }^{149}$

Article 22(1) of the CBD specifically provides that 'the provisions of the Convention shall not affect the rights and obligations of any contracting Parties derived from any existing international agreements, except where the exercise of those rights and obligations would cause serious damage or threat to biological diversity.' In the following subparagraph, the CBD establishes that the contracting parties shall implement this convention (CBD) 'with respect to the marine environment consistently with the rights and obligations of states under the law of the sea. ${ }^{150}$ It appears that the CBD is making a special affirmation with respect to UNCLOS that does not apply to other treaties. In the sense that the negotiators may have introduced this subparagraph to ensure that

146 Brownlie, supra note 1 at 608; VCLT, supra note 2.

147 Brownlie, supra note 1 at 608, especially n 6.

148 VCLT, supra note 2, Article 31(3)(c)

149 Borg, supra note 43 at 269.

150 CBD, supra note 112, Article 22(1)(2). 
if there is a threat to the marine environment or biodiversity the CBD provisions would apply among state parties but without overriding the rights and obligations (including the freedom of fishing) under UNCLOS. Article 311(1) of UNCLOS is open-ended and transfers the competence to decide what should happen in case of a conflict with another treaty to whoever applies the law, as long as it would not affect the rights and obligations under other treaties if these are compatible 'with this Convention and which do not affect the enjoyment by other states Parties' of their rights thereunder. ${ }^{151}$ There is an exception to this provision, however-UNCLOS provisions would apply if there are agreements that derogate from the basic principles relating to the common heritage of mankind under Article 136.

The relationship between UNCLOS and the CBD, as expressed in these two provisions, is a method of streamlining and co-ordinating legal norms, which states may use at the negotiating phase to facilitate harmonization between applicable treaties. These provisions, however, need to be applied cautiously both by users as well as by adjudicating bodies of international disputes because no treaty provision is cast in stone. States may always decide to conclude a new international agreement, and a treaty may also be superseded by the crystallization of a more recent rule of customary international law.

\section{Harmonizing Fragmentation as a Result of Procedural Norms}

In the case of lex specialis and the lex generalis, the VCLT also refers to other procedural legal measures to ensure harmonization between applicable treaties, such as determining the relationship between the general norms and the specialized ones. One can notice that the international legal sources that regulate the conservation of living resources on the high seas range from norm-creating treaties such as UNCLOS to subregional and bilateral agreements. Additionally, some norms relate to particular species such as straddling stocks, marine mammals, and anadromous species that raise issues of priority and specialization as the lex specialis that supplements and fine tunes the lex generalis. International adjudicating bodies are therefore bound to identify the most adequate legal techniques to avoid, minimize, or mitigate the conflict of applicable norms. Their contribution in facilitating the harmonization of fragmented sources of international law is portrayed by the Southern Bluefin Tuna Cases (New Zealand v Japan and Australia v Japan), ${ }^{152}$ which among other issues delved into the relationship between fisheries agreements, namely UNCLOS and the regional Convention on the Conservation of the Southern Bluefin Tuna (CCSBT). ${ }^{153}$ The parties to the dispute, namely Australia and New Zealand, as applicants against Japan as the respondent, asked ITLOS to

151 UNCLOS, supra note 19, Article 311(2)(3).

152 Southern Bluefin Tuna Case (Australia and New Zealand v Japan), ITLOS Case 3 and 4, 39 ILM 1388 (2000) [Southern Bluefin Tuna case].

153 Convention on the Conservation of the Southern Bluefin Tuna, 1819 UNTS 360 [CCSBT]. 
determine which would be the applicable provisions to settle the dispute. All three states were parties to UNCLOS and to the CCSBT.

In a landmark decision, ITLOS concluded that the CCSBT provisions should be applied as they supplement UNCLOS both as lex specialis and as lex posterior. The tribunal held that international legal obligations benefit from a process of accretion and accumulation. ${ }^{154}$ The adjudicating tribunal opted to co-ordinate the interpretation of applicable legal instruments and to consider them as mutually supportive. The Southern Blue Fin Tuna case demonstrates how the ITLOS judges used legal techniques to resolve fragmentation between framework and implementation treaties. It appears that this may happen more readily when treaties have similar objectives or are directly related and are negotiated specifically to supplement one another.

In the World Trade Organization (WTO) disputes United States - Measures Concerning the Importation, Marketing and Sale of Tuna and Tuna Products (Tuna-Dolphin case) ${ }^{155}$ and United States - Import Prohibition of Certain Shrimp and Shrimp Products (Shrimp-Turtle case), ${ }^{156}$ the WTO Appellate Body had to decide a dispute regarding the prohibition under US law of placing on the market fish products that were not harvested via the use of selective fishing gear in the first case and certain fishing techniques in the latter case. The United States refused to allow fish imports that were not caught by selective fishing gear/methods, which were meant to avoid incidental catch of dolphins in the case of tuna products and turtles in the case of shrimp. The applicant states accused the United States of introducing non-tariff trade barriers in breach of WTO rules. The tuna-dolphin and shrimp-turtle 'wars' exposed the inability of the international community at the time to find a solution where the application of environmental trade measures could, if the case was genuine, be used and not necessarily classified as non-tariff trade barriers. In the WTO fisheries trade disputes, the need to safeguard fisheries from over-exploitation was acknowledged, but the use of trade sanctions by states was nontheless branded as a breach of free trade rules. The WTO Appellate Body could not rely on interpretation as a legal technique to achieve harmonization because the application of one norm (trade sanctions) was in direct breach of another (the introduction of non-tariff trade barriers).

154 Southern Bluefin Tuna case, supra note 152 at para 52; see also JA Roach, Dispute Settlement in Specific Situations 7 Geo Int'1 \& Envt'1 L Rev 775 (1995); C Romano, The Southern Bluefin Tuna Dispute: Hints of a World to Come, Like it or Not 32(4) ODIL 313 (2001); T Stephens, The Limits of International Adjudication in International Law: Another Perspective on the Southern Bluefin Tuna Case 19(2) IJMC 177 (2004); Diversification and Expansion, supra note 9 at 21, para 29, for a discussion on the relationship between UNCLOS, supra note 19, and the CCSBT, supra note 153.

155 United States - Measures Concerning the Importation, Marketing and Sale of Tuna and Tuna Products, WTO Doc DS21 (1991) at para 5.42 [Tuna-Dolphin case].

156 United States - Import Prohibition of Certain Shrimp and Shrimp Products, WTO Doc WT/DS58/ AB/R (1998), 38 ILM 118 (1999) [Shrimp-Turtle case] (complaint by India Malaysia and Thailand against US on prohibition of imports of shrimp and shrimp products). 
The WTO Appellate Body in the Shrimp-Turtle case, interpreted the WTO term 'exhaustible natural resources' according to Article XX(g) of the General Agreement on Tariffs and Trade (GATT). ${ }^{157}$ It found that the import ban on shrimp and shrimp products as applied by the United States is inconsistent with Article XI:1 of the 1994 GATT and cannot be justified under Article XX of the 1994 GATT. On 13 July 1998, the United States notified its intention to appeal certain issues of law and legal interpretations developed by the panel. The Appellate Body report was circulated to members on 12 October 1998. The Appellate Body reversed the panel's finding that the US measure at issue is not within the scope of measures permitted under the chapeau of Article XX of GATT but concluded that the US measure, while qualifying for provisional justification under Article $\mathrm{XX}(\mathrm{g})$, failed to meet the requirements of the chapeau of Article XX. It did take into consideration the provisions of other applicable treaties, namely UNCLOS, the CBD, and CITES, among other sources, but still ruled that conservation measures taken in accordance with these treaties constituted a trade barrier in accordance with GATT rules. ${ }^{158}$

\section{Concluding Overview}

The different outcomes between the Southern Bluefin Tuna case and the WTO trade disputes is best explained via the observation made by the ITLOS judges in another case-the MOX Plant Case (Ireland v United Kingdom). ${ }^{159}$ The ITLOS judges held that the application of the same rules by different fora and institutions may vary due to "differences in respective context, object and purpose as well as the subsequent practice of parties and travaux preparatoires.' ${ }^{160}$ One of the salient characteristics and major assets of international law is its dynamism. International norms evolve over time and assume different functions: some serve as a fallback, establishing basic rights and obligations; others specify more detail, adding on to and fine-tuning earlier and more general norms. When norms accumulate and interact, they may complement and supplement each other, but, as discussed earlier, they may also in some cases appear to express different or conflicting rights and obligations. Under these circumstances, the role of international adjudicating bodies is to ensure that the application of the

157 General Agreement on Tariffs and Trade, 55 UNTS 194.

158 Ibid. See < http://www.wto.org/english/tratop_e/dispu_e/cases_e/ds58_e.htm>. On 15 May 1998, the panel report was circulated to members.

159 MOX Plant Case (Ireland v United Kingdom), ITLOS Case 10, 126 ILM 273 at para 50 (2005). The case related to a nuclear facility namely, the MOX Plant at Sellafield in the United Kingdom. Ireland claimed it was causing negative effects on the environment as a result of its operations. The dispute was subject to the multilateral and general rules of UNCLOS, the regional rules of the Convention for the Protection of the Marine Environment of the North-East Atlantic, 32 ILM 1069 (1993) [OSPAR Convention] (since the dispute related to pollution in the North Sea) and the application of EU acquis communautaire as embodied in the EURATOM treaty (because both parties are members of the EU). As a result, the dispute was raised at three different institutional procedures: under ITLOS, under the compulsory dispute settlement procedure set up under the OSPAR Convention and before the European Court of Justice because of the EC/EURATOM treaty.

160 Ibid. 
law safeguards its unity even as norms become more complex and specialized. ${ }^{161}$ Although international tribunals in this respect stand to facilitate the harmonization of applicable rules through the legal techniques referred to earlier, as directed by the VCLT and other treaty provisions, they may be unable to overcome conflicts that cannot be interpreted away. It appears that the most challenging cases for international adjudicating bodies occur when more than one specialized treaty is applicable, as was the case with the Dophin-Tuna ${ }^{162}$ and Shrimp-Turtle ${ }^{163}$ WTO disputes.

The setting up of ITLOS and the other dispute settlement mechanisms in treaties and regional fisheries management organizations is a reaction to the ever-increasing developments under the law of the sea that have transformed it into a specialized branch of international law. These achievements may thus provide stronger and more responsive jurisprudence, but, in itself, this process also risks causing the fragmentation of the international adjudicating system, thus diminishing the ICJ's central role as the principal judicial organ of the United Nations. As we have seen in the WTO cases, it appears that, due to their mandate, international tribunals set up under specialized treaties would have greater difficulty than the ICJ to apply international norms emerging from other sources that conflict with provisions and the spirit of the treaty that constitutes them.

\section{CONCLUSION}

This article has examined various landmark judgments that have influenced the course of behaviour of states in regulating the conservation of living resources in marine areas beyond national jurisdiction. As we have seen, international case law may influence the development of international law particularly during the negotiation of multilateral agreements. States and international organizations have at times reacted to the decisions of international adjudicating bodies by conducting bilateral, regional, and multilateral agreements to further develop the law when international case law has exposed lacunae or the inadequacies of international law in promoting conservation. These decisions have also shed some light on the application of international law in general, particularly when a plurality of sources is involved. It was pertinent to examine decisions of international adjudicating bodies that have not dealt with living marine resources on the high seas but that may have an impact on their international

\footnotetext{
161 See speech by His Excellency Judge Gilbert Guillaume, President of the ICJ to the Sixth Committte of the United Nations General Assembly (UNGA), 'The Proliferation of International Judicial Bodies: The Outlook for the International Legal Order,' delivered on 27 October 2000, at $4, \quad<$ http://www.icj-cij.org/icjwww/ipresscom/SPEECHES/iSpeechPresident_Guillaume_Sixth Committee.20001027.html>.

162 Tuna-Dolphin case, supra note 155.

163 Shrimp-Turtle case, supra note 156.
} 
regulation, particularly when these decisions relate to the responsibility of states beyond national jurisdiction.

Apart from the interpretation of treaties, international case law often serves to confirm or dismiss the arguments put forward by the parties to a dispute as to whether a particular type of state practice is legally binding and may even affirm general principles of law. As we have seen earlier, international adjudicating bodies, relying upon various treaties as well as state practice, have recognized the obligation on the part of any state, whose nationals fish on the high seas, to take necessary conservation measures. ${ }^{164}$ They have also reiterated that the right of access over the resources occurring therein are relative ${ }^{165}$ to those of other states. ${ }^{166}$ At the same time, such bodies have turned down claims made by states regarding their right to take unilateral conservation measures hindering other states from accessing living resources on the high seas. ${ }^{167}$ More recently, even in other cases that deal with international environmental law issues, the ICJ and other international tribunals have examined the legal status of certain forms of state practice, which, as stated earlier, are considered as emergent principles of international law. As post-UNCLOS developments supplement its provisions in stressing this concept of common responsibility towards the conservation of marine living resources occurring on the high seas, international case law provides evidence that the regulation of the freedom of fishing has not evolved within the context of collective undertakings and global management ${ }^{168}$ but, rather, as a means to incorporate environmental concerns in a holistic manner.

This resumé on international case law has therefore highlighted some of the most salient developments underscored by international law in the regulation of living marine resources beyond national jurisdiction. In sum, the exclusive jurisdiction of flag states over living marine resources has thus assumed different meanings over the centuries: from an absolute freedom to one that has sought to maintain a balance of interests between coastal states and flag states whose nationals fish on the high seas. Originally and to a certain extent to this very day, it is largely predominated by economic interests. However, more recently, international law has incorporated conservation obligations that ensure the sustainability of stocks over which both the participants in the fisheries and the entire international community have an interest. Various legal arguments have been made regarding the current state of play, and some issues remain

164 Orrego Vicuna, supra note 24 at 8-22.

165 Brownlie, supra note 1 at 299, who argues that, under international law, sufficiency of grounds for jurisdiction is not merely a question of basic competence but is relative to the rights of other states. See also Shaw, supra note 2 at $646-47$.

166 Behring Sea case, supra note 10; Fisheries Jurisdiction cases (Merits), supra note 15 at 3 and 175.

167 Brownlie, supra note 1 at 252.

168 UN Doc A/AC.138/SC.1/SR. 17 (9 August 1971) where Lebanon, in its statement in the Seabed Committee, had called for the collective organization of high seas fisheries and UN Doc A/AC.138/SC. II/SR.30 (29 March 1972) where Mexico in its statement before the Seabed Committee had suggested the establishment of an international authority for high seas fisheries. 
hypothetical as they have not yet been tried and tested but may indicate where international environmental law may venture in the near or distant future. As Ian Brownlie observes, international adjudicating bodies will undeniably continue to play a pivotal role in this context even if one must be cautious, since Article 59 of the ICJ statute establishes in its proviso that '[ $t$ ]he decision of the court has no binding force except as between the Parties and in respect of that particular case.' 169 Judges sitting in international adjudicating bodies cannot 'make' the law and must interpret and apply norms they consider as applicable in the circumstances. ${ }^{170}$ However, a great deal depends on their approach and attitude when deciding international law cases. Indeed, progress is registered whenever 'the rules of [maritime law] have been the product of mutual accomodation, reasonableness and co-operation.' ${ }^{171}$ These words found in the judgment in the Fisheries Jurisdiction cases remain as valid today as on the day they were delivered.

169 Brownlie, supra note 1 at 21.

170 Ibid at 20.

171 Fisheries Jurisdiction cases, supra note 15 at para 53. 
Reproduced with permission of the copyright owner. Further reproduction prohibited without permission. 